\title{
ニンジンの形態的特性と水分含量によるカロテン含量推定の試み
}

\author{
中川祥治* \\ 公益財団法人農業・環境・健康研究所 410-2311 静岡県伊豆の国市浮橋
}

\section{New Equation to Estimate Carotene Content from Morphological and Moisture Properties of Carrot}

\author{
Shoji Nakagawa* \\ Institute for Agriculture, Medicine and the Environment, Izunokuni, Shizuoka 410-2311
}

\begin{abstract}
The carotene content and its relationship with the characteristics of carrots was analyzed to identify an easier approach to assess the content without using general analytical methods. Carrots of the varieties 'Hon-beni-kintoki' (red color, true bred), 'Koyo-2' (orange color, F1), and 'Shin-kuroda-gosun' (orange color, true bred), cultivated in 1998/99 in Izunokuni City, Shizuoka Prefecture, Japan, were used in the study. Multiple regression analysis was performed using the carotene content as the dependent variable and root color $\left(\mathrm{L}^{*}, \mathrm{a}^{*}\right.$ and $\left.\mathrm{b}^{*}\right)$, moisture content, shape, and vigor as independent variables. As a result, a highly accurate $\left(\mathrm{R}^{2}=0.931, \mathrm{RPD}=3.7\right)$ formula for $\beta$-carotene content estimation was obtained when the root diameter, root moisture content, and leaf weight were set as independent variables. However, the accuracy for estimating the $\alpha$-carotene content (except in 'Hon-beni-kintoki') was low $\left(\mathrm{R}^{2}=0.692, \mathrm{RPD}=2.1\right)$, even when the formula was set as optimal, with the root diameter and root moisture content as independent variables. Of note, the result of covariance analysis showed that the equations for estimating the $\beta$-carotene content of 'Koyo-2' and 'Shin-Kuroda-Gosun' were slightly different. Moreover, since it was necessary to average the data of 15 carrots cultivated under the same conditions to achieve sufficient estimate accuracy, it may be difficult to predict the carotene content of a single carrot using the estimation formula. However, this proposed equation could be applied for comparisons between groups.
\end{abstract}

Key Words : carotenoid, estimate value, functional ingredient, internal quality, root vegetable

キーワード：カロテノイド，機能性成分，根菜，内部品質，推定值

\section{緒 言 \\ カロテンは生体内でビタミン A に転換されるプロビタミ} ンAであり，さらに抗酸化作用（Krinsky・Johnson, 2005; Yeum ら，2009），抗発がん作用（Krinsky・Johnson, 2005; Rock, 2009) 拈よび免疫賦活作用（Chew・Park, 2009）につ いて検討されている。ニンジンはカロテンを豊富に含む 代表的な野菜であり（Britton・Khachik, 2009; Mangels ら, 1993)，それゆ光、ニンジンの品質に関する調査および試 験ではその含量の測定が望まれる。ニンジンのカロテン含 量の測定法としては，有機溶媒で抽出後， HPLCで分画し て吸光度を測定することが一般的である（Barba ら，2006； Khachik, 2009; 満田ら, 2002; Taungbodhitham ら，1998)。 た, HPLCを用いない簡易法としては, 有機溶媒で抽出後, 分光光度計で特定の単一波長（Biswasら，2011）あるいは 複数波長（Nagata 5，2008; 塚澤，2002）の吸光度を測定

2020 年 5 月 30 日 受付. 2020 年 10 月 11 日 受理 本報告の一部は園芸学会令和 2 年度春季大会で発表した。

* Corresponding author. E-mail: showzy@izu.biz
し，それらから算出することが提案されている。いずれに せよこれらの方法は，高価な分析機器や取り扱いに注意が 必要な有機溶媒を使用することから，実施できる拠点は限 定されてしまう。しかし，化学実験設備を持たない小規模 な拠点でも，推定なら実施の可能性がある。ニンジンのカ ロテン含量を推定する方法としては，まず根色を用いるこ とが考えられる．磯野（2011）は金時ニンジンの根色とカ ロテンと同じカロテノイド色素に属するリコペン含量との 関係を示している。 また，Takahataら（1993）はカンショ の根塊切断面色測定值から $\beta$-カロテン含量を推定してい る.これらのことは, ニンジンのカロテン含量を, 色彩色 差計などで測定した根色から推定できる可能性を示唆して いる. 一方, ニンジンのカロテン含量は天候执よび窒素施 肥などの栽培条件の影響を受けるが（Seljåsen ら，2013）, こらいった栽培条件は，当然ながら作物の生育や水分含量 に変化をもたらすことから，これらの特性值からニンジン のカロテン含量の予測が可能ではないかと考えた. そこで 本研究では, 複数の栽培年次や品種のニンジンの, 根色や 各部位の大きさといった形態的な特性と水分含量を独立変 数とし, 従属変数としたカロテン含量を推定するための重 
回帰分析を試みた. その結果, ニンジン群落の平均的な $\beta$-カロテン含量の推定式を得たので以下に報告する.

なお，本研究では，異なる肥料で栽培されたニンジンの 品質を生育量差の影響を除いて比較するために実施した圃 場試験（中川ら，2003）から得られたデータを活用してい る. 本研究は, 新たにカロテン含量の簡易推定の観点から これらデータの解析を試みたものである.

\section{材料および方法}

\section{1. 供試したニンジン}

農業・環境 - 健康研究所付属試験農場（静岡県伊豆の国 市）に打いて，化学肥料および有機質肥料で 1998 年およ び1999年に栽培した複数品種のニンジンを用い, 次項の と扎り生育量, 水分, 根色, $\beta$-カロテン含量および $\alpha$-カロ テン含量を測定した.

1998年は “向陽二号’ ‘本紅金時”，1999年は “向陽二号” と“新黒田五寸”を対象品種とし，いずれも種子はタキイ 種苗(株)から購入した。な抏, “向陽二号” は交配種, ‘新 黒田五寸” は固定種で, ともに橙色系の西洋種である. ‘本 紅金時’は固定種でかつ色素として $\beta$-カロテンよりもリコ ペンを多く含む赤色系の東洋種である（渡辺ら，1988）。 栽培は試験圃場（淡色黒ボク土）に第 1 表に示す施肥条件 を設けて行った。すなおち, 施肥を無施肥条件, リン加安 および熔成リン肥が施用された条件, 被覆りン加安および 熔成リン肥が施用された条件，米糠と豆腐粕を原材料とし たボカシが施用された条件, アルファルファ地上部, 蒸製 骨粉抢よびヤシ油粕灰が施用された条件とした。ただし， 無施肥以外は窒素, リン, カリウムを標準量施用する場合 とその半量を施用する場合に分けた. 以上，9つの施肥条 件区画を乱塊法により 3 反復で試験圃場に配置し, 全部で 27 区画とした． 1 区画は $2 \mathrm{~m} \times 5 \mathrm{~m}$ で，その長辺の方向へ 2 畧作成し， 1 畧に 1 品種を栽培した. すなわち， 1 区画に 2 品種同時に栽培した。 条間は $30 \mathrm{~cm}$ 抢よび株間は $10 \mathrm{~cm}$ と した.
1998 年の播種は 7 月 29 日, 収穫は “向陽二号”が 11 月 20 日，“本紅金時”が 12 月 1 日に行った. 1999年の播種は7 月 27 日, 収穫は“向陽二号”が 11 月 22 日, “新黒田五寸’ が 11 月 27 日に行った。灌水は発芽および初期生育促進の 目的で，本葉第2葉展開期まで行った. 1998 年および 1999 年のニンジン栽培期間中の気温，降水量拈よび日射 量を試験戋場付近で観測しており，後年が前年よりも降水 量が生育中期で少なく，後期で多い傾向であった。また， ニンジンの収穫後は無施肥でライムギを栽培した。

\section{2. 調査および分析}

収穫日に各品種 1 畧 2 条のらち区画中央側の 1 条から, 生育中庸で外観良好の 5 個体を採取し，根部を水で洗浄す るとともにその先端の細根を取り除いた．次いで，1個体 ずつ根長，葉数および最大葉長を測定した後，根部と葉部 に切断してそれぞれの重量を測定した．根部は肩部，中間 部拈よび先端部に長さで3 等分に切断し，さらにその中間 部を縦方向へ半分に切断した. その後, 中間部の切断面 から根直径抢よび芯部直径を測定するとともに，肉部の $\mathrm{L}^{*}, \mathrm{a}^{*}$ および $\mathrm{b}$ *值を色彩色差計（NR-3000, 日本電色工業 (株)）により C光源モードで測定した（第 1 図)。芯部は 多くの個体で色が不均一であったため測定しなかった，そ の後, 中間部は小切片に切断し, 5 個体の切片を等量ずつ 混合して水分, $\beta$ - および $\alpha$-カロテン含量の測定用試料と

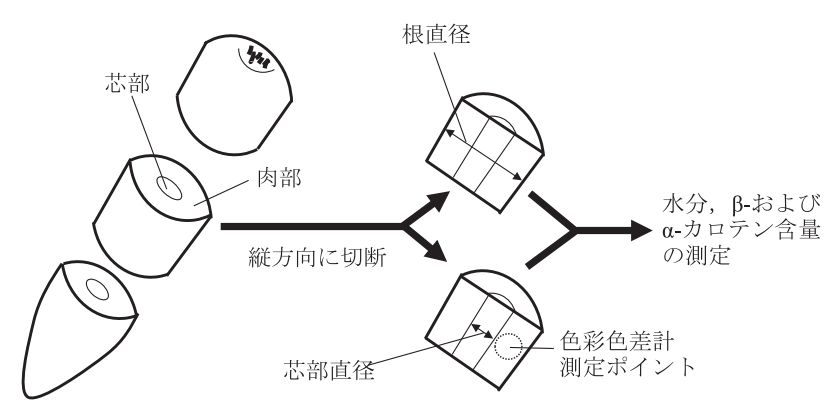

第1図各種測定および分析のためのニンジン根部の処理

第 1 表 供試ニンジンの栽培に拈ける施肥条件

\begin{tabular}{|c|c|c|c|c|}
\hline \multirow{2}{*}{ 番号 } & \multirow{2}{*}{ 施用肥料扣よび施用量 $\left(\mathrm{g} ・ \mathrm{~m}^{-2} ・ \mathrm{year}^{-1}\right)^{\mathrm{z}}$} & \multicolumn{3}{|c|}{ 成分あたり施用量 ${ }^{\mathrm{y}}\left(\mathrm{g} \cdot \mathrm{m}^{-2} \cdot \mathrm{year}^{-1}\right)$} \\
\hline & & $\mathrm{N}$ & $\mathrm{P}$ & $\mathrm{K}$ \\
\hline & 無施肥 & 0.0 & 0.0 & 0.0 \\
\hline & リン加安 53, 熔成リン肥 37 & 7.5 & 6.0 & 6.4 \\
\hline & リン加安 107, 熔成リン肥 74 & 15.1 & 12.0 & 12.9 \\
\hline & 被覆リン加安 58，熔成リン肥 36 & 7.5 & 6.0 & 7.0 \\
\hline 5 & 被覆リン加安 116 , 熔成リン肥 72 & 15.1 & 12.0 & 13.9 \\
\hline 6 & 米糠 +豆腐粕ボカシ 240 & 7.4 & 6.0 & 5.5 \\
\hline 7 & 米糠 +豆腐粕ボカシ 480 & 14.9 & 12.0 & 11.0 \\
\hline 8 & アルファルファ地上部 $735 ／ 825^{\mathrm{x}}$, 蒸製骨粉 60, ヤシ油粕灰 $10 ／ 8$ & $7.5 / 7.6$ & $6.1 / 6.2$ & $5.4 / 5.4$ \\
\hline 9 & アルファルファ地上部 $1470 / 1650$, 蒸製骨粉 120, ヤシ油粕灰 $21 / 15$ & $15.1 / 15.3$ & $12.1 / 12.3$ & $11.0 / 10.6$ \\
\hline
\end{tabular}

${ }^{\mathrm{z}} 2 ， 3 ， 6$ 拈よび 7 番は元肥と追肥の 2 回に分けて $1 / 2$ 量ずつ施用

$\mathrm{y}$ 成分は酸化物ではなく単体で表示

x 1998 年/1999年 
した. 水分は $30 \mathrm{~mL}$ 容ビーカーに切片 $14 \mathrm{~g}$ 程度を入れ, 定 温乾燥器 (NDO-450ND, 東京理化器械(株) ) により $105^{\circ} \mathrm{C}$ で 24 時間乾燥させて求めた. 乾燥前後の重量を測定した 電子天科は $32 \mathrm{~g}$ までの最小表示が $0.01 \mathrm{mg}$ 抢よび $180 \mathrm{~g}$ ま での最小表示が $0.1 \mathrm{mg}$ のの（ER-182A，（株）エー・アン ド・デイ）を用いた～$\beta$ - 抢よび $\alpha$-カロテン含量は分析まで 試料を密封して $-85^{\circ} \mathrm{C}$ の冷凍庫で保存し, アセトン抽出と HPLC 法を組久合わせる満田ら（2002）の方法を参考に測 定した，すなわち，凍結した切片をそのまま家庭用のブ レンダーでシャーベット状に粗砕し, その $5 \mathrm{~g}$ を $50 \mathrm{~mL}$ 容 の遠沈管に入れ, アセトン $30 \mathrm{~mL}$ を加光た後, 外径 $20 \mathrm{~mm}$ のジェネレーターシャフトを装着した吸い込久式のホモジ ナイザー（Polytron PT10-35, KINEMATICA 社) で10 秒間 ホモジナイズした。懸濁液は $3000 \mathrm{rpm}$ で 10 分間遠心分離 し, 上澄みを $100 \mathrm{~mL}$ 容褐色メスフラスコに入れた。続い て遠沈管内の残椬にアセトン $30 \mathrm{~mL}$ を加えて上記と同様の 操作を 2 回繰り返し, 合わせた上澄みにアセトン約 $10 \mathrm{~mL}$ を加えて全部で $100 \mathrm{~mL}$ 定容とした。な抏，上記で使用し たアセトンには抗酸化剂としてピロガロールを1\%添加し た. $100 \mathrm{~mL}$ に定容したアセトン抽出液は一部を $0.45 \mu \mathrm{m}$ の メンブレンフィルターでろ過し, 万液の $20 \mu \mathrm{L}$ HPLC （LC-9A，（株）島津製作所）に注入した. $\beta$-および $\alpha$-カロテ ンの標準試薬はそれぞれ和光純薬工業(株)およびシグ マアルドリッチジャパン(合)から購入した. HPLCの動 作条件およびクロマトグラムを第 2 図に示す。一方, 葉部 は通風乾燥器 (WFO-1000SD, 東京理化器械(株) ) 用い て $80^{\circ} \mathrm{C} て ゙ 48$ 時間乾燥させ，水分を測定した。乾燥前後の 重量を測定した電子天秤は $600 \mathrm{~g}$ をでの最小表示が $0.01 \mathrm{~g}$ 拈よび $3100 \mathrm{~g}$ をでの最小表示が $0.1 \mathrm{~g}$ のもの（FX-3200, (株)エー・アンド・デイ）を用いた。

\section{3. 統計処理}

根部の水分, $\beta$ - 抢よび $\alpha$-カロ テン含量では 1 区画 1 品種 当たり 5 個体の混合試料の測定値を，その他の測定項目で は 5 個体の測定值の平均値を最小単位のデータとした，そ して, 108 組 $(2$ 年 $\times 2$ 品種 $\times 9$ 施肥条件 $\times 3$ 区画での一連 の測定值群, 以下 $\mathrm{n}=108)$, もしくは $\alpha$-カロテン含量が極 少であった ‘本紅金時”を除く $\mathrm{n}=81$ のデータを用いて測 定値の概要を分位系で算出した. 次いで, カロテン含量推 定の可能性を探るため, 同じ $\mathrm{n}=108$ （もしくは $\mathrm{n}=81 ） の$ データを用い, カロテン含量を従属変数, カロテン含量以 外の測定值にこれらの演算值を加えた 20 項目（第 3 表参 照）を独立変数として単回帰分析を行った。 また，力口 テン含量を従属変数とし, 前述の 20 項目から $\mathrm{a}^{*} / \mathrm{b}^{*}$ や葉 重/根重といった比の值を含む7項目を除いた 13 項目を 独立変数とする重回帰分析を行った．分析には前述の $\mathrm{n}=108$ （もしくは $\mathrm{n}=81 ）$ のデータを用いる場合と, 各 3 区

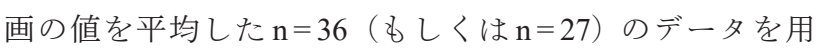
いる場合の 2 通りとした。 そして, 多重共線性の排除（VIF ఏ10）を前提に, 変数増減法により最適な推定式を探索し

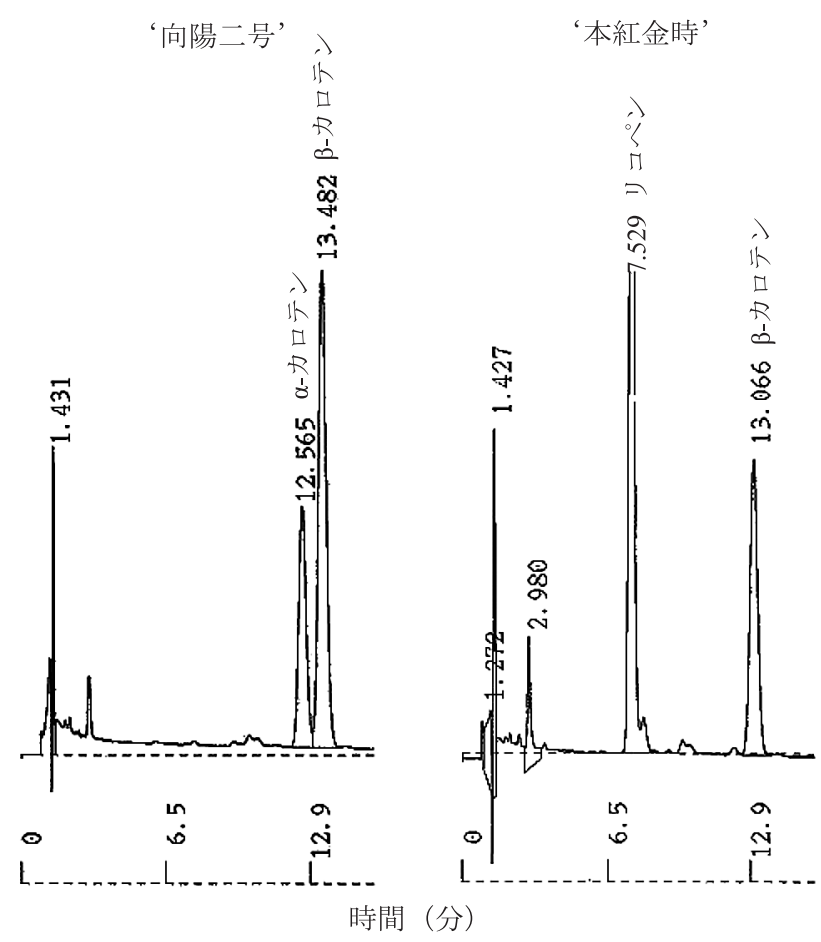

第2図 ニンジン抽出液の HPLC クロマトグラム カラムはUnisil Q C18 $(150 \mathrm{~mm} \times 4 \mathrm{~mm}$, 粒子径 $5 \mu \mathrm{m})$ (ジーエルサイエンス(株)), 移動相はアセトニトリル 70 : エタノール $30(\mathrm{v}: \mathrm{v})$, 流速は $1.0 \mathrm{~mL} /$ 分, カラム 温度は室温, 吸光度測定波長は $450 \mathrm{~nm}$ ‘新黒田五寸’は“向陽二号’と浪涪同じ

た。また，K-fold 法（内田，2013）により，選択した推定 式の精度を検証した。 すなわち，対象全データを無作為に 3 グループに等分割し，そのらち任意の 1 グループを検量 線評価群，2グループを検量線作成群とした．次いで，グ ループを順次交代させて, 全部で 3 回の検証を行い, 平均 で評価した. 重回帰分析の従属変数であるカロテン含量推 定值と実測值の関係が品種や栽培年で異なるか否かにつ いては, 品種や栽培年を要因, 推定值を共変量, 実測值を 従属変数とした共分散分析で検討した．各種統計処理は StatView 5.0（SAS Institute Japan(株)）抒よびR 3.3.4（R Development Core Team, 2017）を用いて行った.

\section{結 果}

\section{1. 測定値の概要}

各測定值の概要を第 2 表に示す。“本紅金時’，“向陽二 号’ (1998 年)，“新黒田五寸’ 打よび“向陽二号’（1999年） の $\beta$-カロテン含量（各 $\mathrm{n}=27 ）$ の四分位範囲は，それ年れ $7.3,10.4,10.1$ 打よび $9.8 \mathrm{mg} \cdot \mathrm{kg}^{-1} \mathrm{FW}$ であった。年度抒 よび品種を込みとした全体 $(\mathrm{n}=108)$ の四分位範囲は $26.6 \mathrm{mg} \cdot \mathrm{kg}^{-1} \mathrm{FW}$ となったが，これは前述の施肥条件に加 えて, 各品種の中央值, 第 1 四分位拉よび第 3 四分位から わかるように, 向陽二号 > 新黒田五寸 > 本紅金時といら品 種間の含量差が反映されたものであろう。

一方， $\alpha$-カロテン含量の四分位範囲は “向陽二号”

$(1998$ 
第 2 表 供試ニンジンの測定值概要

\begin{tabular}{|c|c|c|c|c|c|c|c|c|c|c|c|c|c|c|c|c|}
\hline & & & \multicolumn{3}{|c|}{ 肉部根色 (C 光源) } & \multirow{2}{*}{$\begin{array}{c}\text { 根重 } \\
(\mathrm{g})\end{array}$} & \multirow{2}{*}{$\begin{array}{l}\text { 根長 } \\
(\mathrm{cm})\end{array}$} & \multirow{2}{*}{$\begin{array}{c}\text { 根直径 } \\
(\mathrm{cm})\end{array}$} & \multirow{2}{*}{$\begin{array}{c}\text { 芯部直径 } \\
(\mathrm{cm})\end{array}$} & \multirow{2}{*}{$\begin{array}{c}\text { 根水分 } \\
(\%)\end{array}$} & \multirow{2}{*}{$\begin{array}{c}\text { 葉重 } \\
(\mathrm{g})\end{array}$} & \multirow{2}{*}{$\begin{array}{l}\text { 葉数 } \\
\text { (枚) }\end{array}$} & \multirow{2}{*}{$\begin{array}{c}\text { 最大葉長 } \\
(\mathrm{cm})\end{array}$} & \multirow{2}{*}{$\begin{array}{c}\text { 葉水分 } \\
(\%)\end{array}$} & \\
\hline & & & $\mathrm{L}^{*}$ & $a^{*}$ & $\mathrm{~b}^{*}$ & & & & & & & & & & & \\
\hline \multirow{8}{*}{$\begin{array}{l}1998 \\
\text { 年 }\end{array}$} & \multirow{4}{*}{$\begin{array}{l}\text { 本紅金時 } \\
(\mathrm{n}=27)\end{array}$} & 中央値 & 56.0 & 34.8 & 31.3 & 157 & 31.4 & 2.39 & 0.71 & 87.3 & 40.9 & 13.0 & 36.0 & 82.0 & 40.2 & \multirow{4}{*}{ Trace } \\
\hline & & 第 1 四分位 & 55.2 & 33.0 & 30.4 & 145 & 31.1 & 2.32 & 0.66 & 87.0 & 35.7 & 12.0 & 34.0 & 81.1 & 37.1 & \\
\hline & & 第 3 四分位 & 57.3 & 35.8 & 31.8 & 169 & 32.9 & 2.54 & 0.77 & 87.6 & 49.9 & 13.5 & 37.9 & 82.8 & 44.4 & \\
\hline & & 四分位範囲 & 2.1 & 2.8 & 1.4 & 24 & 1.8 & 0.22 & 0.11 & 0.6 & 14.2 & 1.5 & 4.0 & 1.7 & 7.3 & \\
\hline & \multirow{4}{*}{$\begin{array}{c}\text { 向陽二号 } \\
(\mathrm{n}=27)\end{array}$} & 中央値 & 62.3 & 26.2 & 41.2 & 211 & 18.3 & 3.91 & 1.63 & 89.2 & 32.9 & 8.8 & 36.1 & 84.3 & 71.5 & 40.5 \\
\hline & & 第 1 四分位 & 61.8 & 24.9 & 40.5 & 203 & 17.8 & 3.74 & 1.55 & 88.9 & 28.9 & 8.3 & 35.2 & 84.1 & 66.6 & 37.2 \\
\hline & & 第 3 四分位 & 63.1 & 27.0 & 42.5 & 239 & 18.7 & 4.08 & 1.69 & 89.5 & 36.3 & 9.2 & 37.5 & 84.7 & 76.9 & 46.9 \\
\hline & & 四分位範囲 & 1.3 & 2.0 & 2.1 & 36 & 0.9 & 0.34 & 0.14 & 0.5 & 7.4 & 0.9 & 2.3 & 0.6 & 10.4 & 9.7 \\
\hline \multirow{8}{*}{$\begin{array}{l}1999 \\
\text { 年 }\end{array}$} & \multirow{4}{*}{$\begin{array}{c}\text { 新黑田五寸 } \\
\quad(n=27)\end{array}$} & 中央値 & 60.0 & 29.2 & 41.2 & 258 & 21.1 & 3.96 & 1.66 & 89.9 & 55.2 & 11.4 & 41.5 & 83.8 & 51.5 & 37.3 \\
\hline & & 第 1 四分位 & 59.7 & 28.4 & 40.1 & 238 & 20.7 & 3.76 & 1.55 & 89.8 & 48.6 & 10.9 & 39.2 & 83.1 & 45.3 & 33.9 \\
\hline & & 第 3 四分位 & 60.7 & 30.3 & 43.0 & 303 & 21.6 & 4.20 & 1.81 & 90.1 & 60.8 & 12.0 & 45.2 & 84.5 & 55.4 & 41.7 \\
\hline & & 四分位範囲 & 1.0 & 1.9 & 2.9 & 65 & 0.9 & 0.44 & 0.26 & 0.3 & 12.2 & 1.1 & 6.0 & 1.4 & 10.1 & 7.8 \\
\hline & \multirow{4}{*}{$\begin{array}{c}\text { 向陽二号 } \\
(\mathrm{n}=27)\end{array}$} & 中央値 & 60.3 & 27.4 & 41.4 & 287 & 20.3 & 4.10 & 1.75 & 89.9 & 31.3 & 8.4 & 35.8 & 84.3 & 71.9 & 35.5 \\
\hline & & 第 1 四分位 & 59.6 & 26.8 & 40.8 & 254 & 19.5 & 3.96 & 1.66 & 89.6 & 25.8 & 7.7 & 34.5 & 83.9 & 68.1 & 33.6 \\
\hline & & 第3 四分位 & 60.9 & 28.0 & 42.6 & 321 & 20.9 & 4.33 & 1.90 & 90.2 & 38.0 & 9.4 & 38.3 & 84.8 & 77.9 & 39.2 \\
\hline & & 四分位範囲 & 1.3 & 1.2 & 1.7 & 67 & 1.5 & 0.37 & 0.25 & 0.6 & 12.3 & 1.7 & 3.8 & 0.9 & 9.8 & 5.6 \\
\hline \multirow{4}{*}{\multicolumn{2}{|c|}{$\begin{array}{c}\text { 全体 } \\
(\mathrm{n}=108)\end{array}$}} & 中央値 & 60.2 & 28.1 & 40.8 & 233 & 20.7 & 3.90 & 1.59 & 89.5 & 37.3 & 10.0 & 36.6 & 84.0 & 60.1 & \\
\hline & & 第 1 四分位 & 58.4 & 26.8 & 33.7 & 171 & 18.9 & 2.84 & 1.05 & 88.4 & 29.4 & 8.8 & 34.8 & 82.9 & 45.1 & \\
\hline & & 第 3 四分位 & 61.6 & 31.3 & 42.1 & 278 & 25.3 & 4.10 & 1.72 & 89.9 & 49.1 & 12.0 & 40.2 & 84.5 & 71.6 & \\
\hline & & 四分位範囲 & 3.2 & 4.6 & 8.5 & 107 & 6.4 & 1.27 & 0.67 & 1.5 & 19.7 & 3.3 & 5.4 & 1.6 & 26.6 & \\
\hline \multirow{4}{*}{\multicolumn{2}{|c|}{$\begin{array}{c}\text { 全体 } \\
\text { (本紅金時除く) } \\
(\mathrm{n}=81)\end{array}$}} & 中央值 & 60.9 & 27.4 & 41.4 & 248 & 19.7 & 3.99 & 1.67 & 89.7 & 35.7 & 9.2 & 37.0 & 84.2 & 68.1 & 37.8 \\
\hline & & 第 1 四分位 & 59.8 & 26.2 & 40.6 & 209 & 18.4 & 3.82 & 1.55 & 89.3 & 29.0 & 8.4 & 35.2 & 83.7 & 54.2 & 34.8 \\
\hline & & 第 3 四分位 & 62.0 & 28.6 & 42.6 & 295 & 21.0 & 4.18 & 1.78 & 90.0 & 46.1 & 10.8 & 40.7 & 84.8 & 75.3 & 41.8 \\
\hline & & 四分位範囲 & 2.2 & 2.3 & 2.0 & 86 & 2.5 & 0.36 & 0.23 & 0.7 & 17.1 & 2.4 & 5.5 & 1.0 & 21.2 & 7.0 \\
\hline
\end{tabular}

表中の数值は収穫した 1 区画内 5 個体ニンジンでの平均值を 1 データとして計算した結果を示す

年), “新黒田五寸’および“向陽二号”(1999年)の順で9.7, 7.8 および $5.6 \mathrm{mg} \mathrm{kg}^{-1} \mathrm{FW}$ であった（“本紅金時’は含量 が痕跡程度のため対象外). 以上の值は $\beta$-カロテンの場合 よりも小さいが, これは $\alpha$-カロテン含量が $\beta$-カロテンの 半分〜半分強であったことの反映といえる. 両カロテンは ともにカロテノイド合成経路でリコピンから生合成される が (Cazzonelli・Pogson, 2010), $\beta$-カロテンが検出される ニンジン品種群（白色系以外）では， $\alpha$-カロテン含量は $\beta$ カロテン含量に対し, 総じて半分以下であったことが報告 されている (Nicolle ら, 2004)。本研究では, “本紅金時” を除く全体の $\beta$-カロテン含量 $(\mathrm{n}=81)$ の四分位範囲が $21.2 \mathrm{mg} \cdot \mathrm{kg}^{-1} \mathrm{FW}$ であったのに対し $\alpha$-カロテンでは 3 分の 1 の $7.0 \mathrm{mg} \cdot \mathrm{kg}^{-1} \mathrm{FW}$ であった. この $\alpha$-カロテンでの值の 低さは, 前述した $\alpha$-カロテン含量の少なさに加えて, 品 種間の $\alpha$-カロテン含量の差の小ささが要因であろら.

\section{2. 単回帰分析によるカロテン含量の推定}

カロテン含量を従属変数, 各測定項目を独立変数とした 単回帰分析の結果を第 3 表に示す. 決定係数 ( $\mathrm{R}^{2}$ 值) が最 も高かった独立変数とその值は， $\beta$-カロテン含量 $(\mathrm{n}=108)$ が従属変数の場合で $\mathrm{b}^{*} の 0.572$, “本紅金時”を除く $\beta$-力 ロテン含量 $(n=81)$ が従属変数の場合で根長/根直径の 0.391， $\alpha$-カロテン含量 $(\mathrm{n}=81)$ が従属変数の場合で $\mathrm{b} *$ の
0.304 であった. これら $\mathrm{R}^{2}$ 值はいずれも統計的に有意 $(\mathrm{P}<0.0001)$ であり, 特に $\mathrm{b} *$ はカロテン含量と比較的強い 関係があると思われたが，含量の推定に利用できるほどの 水準ではなかった.

\section{3. 重回帰分析によるカロテン含量の推定}

まず， 1 区画 5 個体の平均值をデータ単位として，全 データ（n=108）を用いた $\beta$-カロテン含量の推定式は,

$\beta$-カロテン含量推定值 $\left(\mathrm{mg} \cdot \mathrm{kg}^{-1}\right)=825+28.7$

$\times$ 根直径 $(\mathrm{cm})-9.49 \times$ 根水分 $(\%)-0.57 \times$ 葉重 $(\mathrm{g})$

第 1 式

ここで，すべての係数の $\mathrm{P}$ 值は 0.0001 未満，標準偏回帰 係数は根直径が 1.37 , 根水分が -0.67 拈よび葉重が -0.51 , VIFは1.2〜3.3であった.

“本紅金時”を除くデータ $(\mathrm{n}=81)$ を用いた $\alpha$-カロテン 含量の推定式は,

$\alpha$-カロテン含量推定值 $\left(\mathrm{mg} \cdot \mathrm{kg}^{-1}\right)=570+8.9$

$\times$ 根直径 $(\mathrm{cm})-6.32 \times$ 根水分 $(\%)$

第 2 式

ここで, すべての係数の $\mathrm{P}$ 值は 0.0001 未満, 標準偏回帰 係数は根直径が 0.47 および根水分が -0.47 , VIF は 1.0 で あった．第 1 式および第 2 式から算出されるカロテン含量 
第3 表 ニンジンの各特性によるカロテン含量推定の単回帰分析に拈ける回帰係数と決定係数

\begin{tabular}{|c|c|c|c|c|c|c|c|c|}
\hline & \multicolumn{3}{|c|}{ 回帰係数 } & \multicolumn{5}{|c|}{$\mathrm{R}^{2}$} \\
\hline & \multicolumn{2}{|c|}{$\beta$-カロテン含量 } & \multirow{2}{*}{$\begin{array}{l}\alpha \text {-カロテン含量 } \\
\quad(\mathrm{n}=81)^{\mathrm{z}}\end{array}$} & \multicolumn{4}{|c|}{$\beta$-カロテン含量 } & \multirow{2}{*}{$\begin{array}{c}\alpha \text {-カロテン含量 } \\
\quad(\mathrm{n}=81)^{\mathrm{z}}\end{array}$} \\
\hline & $(\mathrm{n}=108)$ & $(\mathrm{n}=81)^{\mathrm{z}}$ & & $(\mathrm{n}=$ & 108) & $(n=81$ & $1)^{\mathrm{z}}$ & \\
\hline $\mathrm{L}^{*}$ & 3.53 & 1.26 & 0.69 & 0.312 & $* * * *$ & 0.021 & & 0.026 \\
\hline$a^{*}$ & -2.14 & 0.03 & 1.00 & 0.260 & $* * * *$ & 0.000 & & $0.121 * *$ \\
\hline$b^{*}$ & 2.45 & 3.15 & 1.70 & 0.572 & $* * * *$ & $0.257 *$ & $* * * *$ & $0.304 * * * *$ \\
\hline $\mathrm{a}^{*} / \mathrm{b}^{*}$ & -54.73 & -136.06 & 1.67 & 0.472 & $* * * *$ & $0.177 *$ & $* * * *$ & 0.000 \\
\hline$\left(a^{* 2}+b^{* 2}\right)^{1 / 2}$ & 2.85 & 1.52 & 1.18 & 0.282 & $* * * *$ & $0.103 *$ & & $0.256 * * * *$ \\
\hline $\mathrm{L}^{*} \times\left(\mathrm{b}^{*} / \mathrm{a}^{*}\right)^{\mathrm{y}}$ & 0.58 & 0.63 & 0.03 & 0.487 & $* * * *$ & $0.122 *$ & $* *$ & 0.001 \\
\hline 根重 ～～～～～～ & 0.12 & 0.05 & 0.03 & 0.293 & $* * * *$ & $0.050 *$ & & $0.084 * *$ \\
\hline 根長 & -1.91 & -1.51 & 0.27 & 0.444 & $* * * *$ & 0.033 & & 0.004 \\
\hline 根重/根長 & 2.73 & 2.07 & 0.96 & 0.504 & $* * * *$ & $0.144 *$ & $* * *$ & $0.127 * *$ \\
\hline 根直径 & 15.54 & 23.41 & 9.24 & 0.549 & $* * * *$ & $0.213 *$ & $* * * *$ & $0.240 * * * *$ \\
\hline 根重／根直径 & 0.12 & 0.12 & 0.11 & 0.008 & & 0.011 & & 0.036 \\
\hline 根長／根直径 & -2.97 & -17.77 & -6.37 & 0.494 & $* * * *$ & $0.391 *$ & $* * * *$ & $0.203 * * * *$ \\
\hline 芯部直径 & 24.27 & 23.41 & 12.00 & 0.507 & $* * * *$ & $0.130 *$ & $* * *$ & $0.138 * * *$ \\
\hline 根直径／芯部直径 & -18.27 & -6.74 & -2.12 & 0.387 & $* * * *$ & 0.006 & & 0.002 \\
\hline 根水分 & 6.44 & -12.98 & -6.57 & 0.209 & $* * * *$ & $0.225 *$ & $* * * *$ & $0.233 * * * *$ \\
\hline 葉重 & -0.27 & -0.28 & 0.15 & 0.058 & $*$ & $0.095 *$ & & $0.108 * *$ \\
\hline 葉数 & -5.20 & -4.27 & 0.75 & 0.436 & $* * * *$ & $0.235 *$ & $* * * *$ & 0.030 \\
\hline 最大葉長 & 0.31 & -0.17 & 0.55 & 0.009 & & 0.004 & & $0.174 * * * *$ \\
\hline 葉水分 & 5.41 & 0.07 & -2.28 & 0.198 & $* * * *$ & 0.000 & & $0.084 * *$ \\
\hline 葉重／根重 & -181.52 & -178.19 & 25.54 & 0.555 & $* * * *$ & $0.327 *$ & $* * * *$ & 0.027 \\
\hline
\end{tabular}

各特性の測定単位は第 2 表に示した

1 区画内 5 個体の平均值が 1 データ

$\beta$-カロテン含量では 2 品種 $\times 9$ 施肥条件 $\times 3$ 区画 $\times 2$ 年で $\mathrm{n}=108$

z“本紅金時”を除外

y川城（2003）を参考にした

*,**,***物よび****はそれぞれ $\mathrm{P}<0.05,0.01 ， 0.001$ および 0.0001 を示す

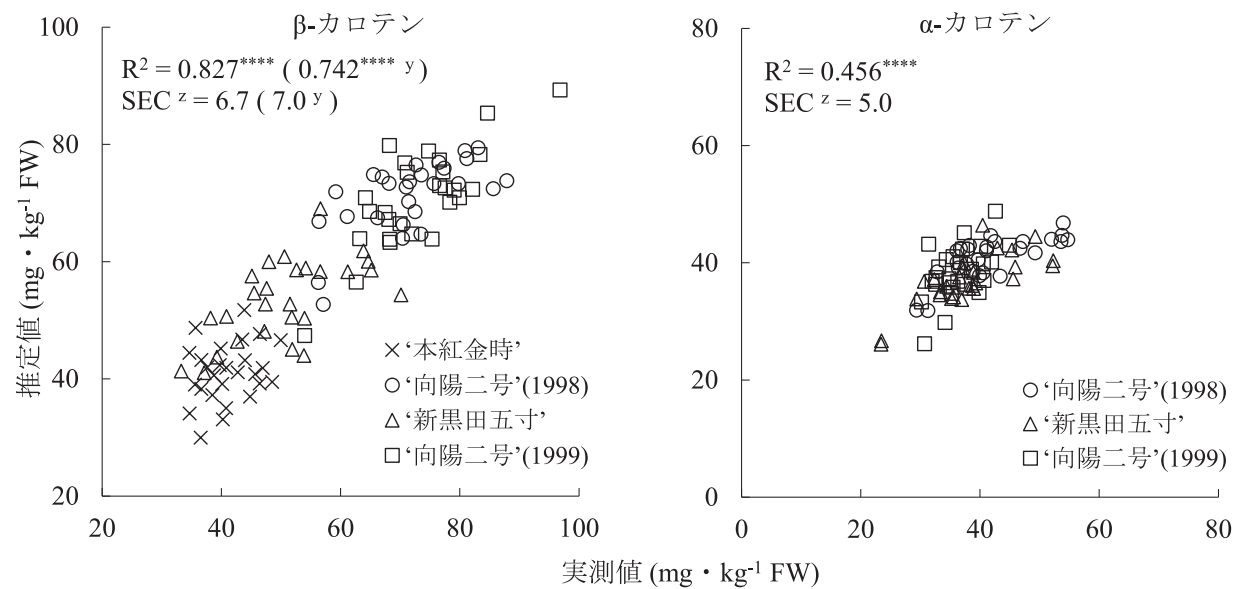

第 3 図 ニンジンの形態的特性と水分含量から推定したカロテン含量の推定値と実測值の関係（5個体平均をデータ単位とした 場合)

$\beta$-カロテン含量推定值 $\left(\mathrm{mg} \cdot \mathrm{kg}^{-1}\right)=825+28.7 \times$ 根直径 $(\mathrm{cm})-9.49 \times$ 根水分 $(\%)-0.57 \times$ 葉重 $(\mathrm{g})$

$\alpha$-カロテン含量推定值 $\left(\mathrm{mg} \cdot \mathrm{kg}^{-1}\right)=570+8.9 \times$ 根直径 $(\mathrm{cm})-6.32 \times$ 根水分 $(\%)$

$\beta$-カロテンでは $\mathrm{n}=108$, また, “本紅金時”を除いた $\beta$-カロテン拈よび $\alpha$-カロテンでは $\mathrm{n}=81$

$\mathrm{z}$ 検量線標準詋差 $(\mathrm{SEC})$ は $\left[\Sigma(\mathrm{Xi}-\mathrm{Yi})^{2} /(\mathrm{n}-\mathrm{p}-1)\right]^{1 / 2}$ で算出され，ここでXi は個々の実測值，Yi は個々の推定値，nは上述の 值抢よび $\mathrm{p}$ は推定のための重回帰式に打ける独立変数の数を示す（夏賀ら，1992）

y ‘本紅金時”を除いた場合

****は $\mathrm{P}<0.0001$ を示す 


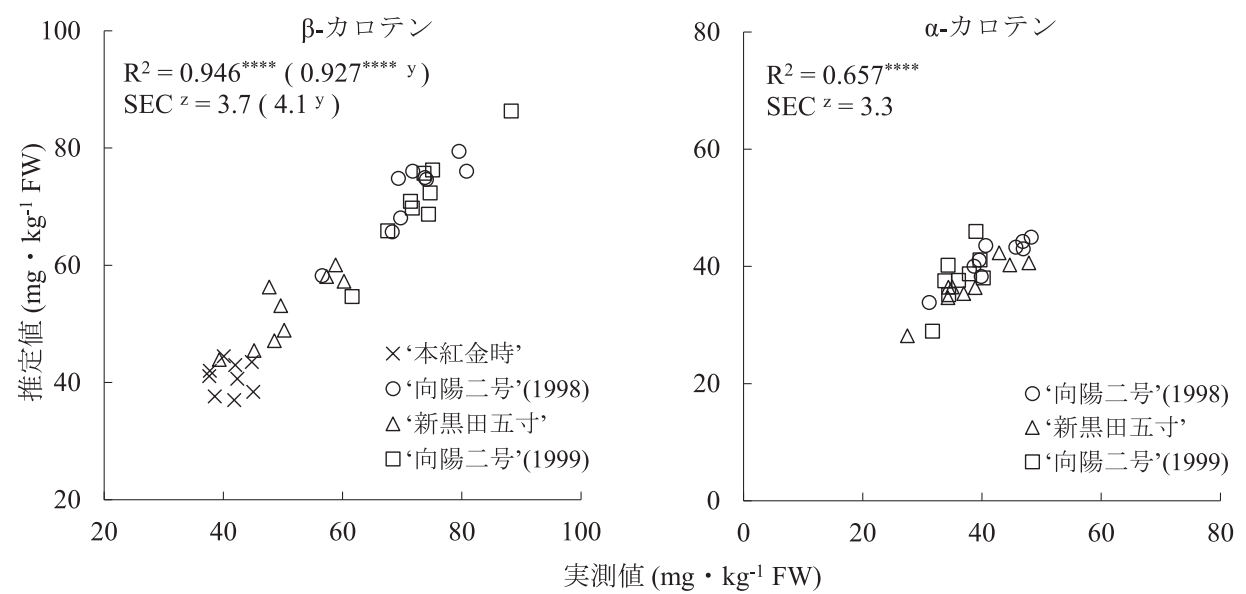

第 4 図 ニンジンの形態的特性と水分含量から推定したカロテン含量の推定值と実測值の関係（15個体平均をデータ単位とした 場合)

$\beta$-カロテン含量推定值 $\left(\mathrm{mg} \cdot \mathrm{kg}^{-1}\right)=966+31.2 \times$ 根直径 $(\mathrm{cm})-11.2 \times$ 根水分 $(\%)-0.62 \times$ 葉重 $(\mathrm{g})$ $\alpha$-カロテン含量推定值 $\left(\mathrm{mg} \cdot \mathrm{kg}^{-1}\right)=646+9.5 \times$ 根直径 $(\mathrm{cm})-7.19 \times$ 根水分 $(\%)$

$\beta$-カロテンでは $\mathrm{n}=36$ ，また，“本紅金時”を除いた $\beta$-カロテンおよび $\alpha$-カロテンでは $\mathrm{n}=27$

$\mathrm{z}$ 検量線標準䛊差 $(\mathrm{SEC})$ は $\left[\Sigma(\mathrm{Xi}-\mathrm{Yi})^{2} /(\mathrm{n}-\mathrm{p}-1)\right]^{1 / 2}$ で算出され, ここでXi は個々の実測値, Yi は個々の推定値, $\mathrm{n}$ は上述の值 および $\mathrm{p}$ は推定のための重回帰式に打ける独立変数の数を示す（夏賀ら，1992）

y ‘本紅金時”を除いた場合

****は $\mathrm{P}<0.0001$ を示す

の推定值と HPLC 実測值との関係は第 3 図のとおりで, $\mathrm{R}^{2}$ 值は $\beta$ - および $\alpha$-カロテンでそれぞれ 0.827 および 0.456 (P はともに<0.0001）であった. $\beta$-カロテンについて， $\alpha$-カ ロテンと条件を揃えるべく‘本紅金時’を除いたデータ $(\mathrm{n}=81)$ を用いても， $\mathrm{R}^{2}$ 值は $0.742 （ \mathrm{P}<0.0001 ）$ で（推定式 省略)，いずれにしても $\alpha$-カロテンより $\beta$-カロテンの方が $\mathrm{R}^{2}$ 值は高かった。

次いで，3区画 15 個体分の平均值をデータ単位とした 場合, 全データ $(\mathrm{n}=36)$ を用いた $\beta$-カロテン含量の推定 式は,

$\beta$-カロテン含量推定値 $\left(\mathrm{mg} \cdot \mathrm{kg}^{-1}\right)=966+31.2$

$\times$ 根直径 $(\mathrm{cm})-11.2 \times$ 根水分 $(\mathrm{g})-0.62 \times$ 葉重 $(\mathrm{g})$

第 3 式

ここで，すべての係数のP 值は 0.0001 未満，標準偏回帰 係数は根直径が 1.55 , 根水分が -0.81 打よび葉重が -0.55 , VIF は $1.1 〜 4.1$ であった。

‘本紅金時’を除くデータ（n=27）を用いた $\alpha$-カロテン 含量の推定式は,

$\alpha$-カロテン含量推定值 $\left(\mathrm{mg} \cdot \mathrm{kg}^{-1}\right)=646+9.5$

$\times$ 根直径 $(\mathrm{cm})-7.19 \times$ 根水分 $(\%)$

第 4 式

ここで，すべての係数の P 值は 0.0001 未満，標準偏回帰 係数は根直径が 0.58 打よび根水分が -0.56, VIF は 1.0 で あった。第 3 式拉よ゙第 4 式から算出されるカロテン含量 の推定值と実測值との関係は第 4 図に示すと颃りで， $\mathrm{R}^{2}$

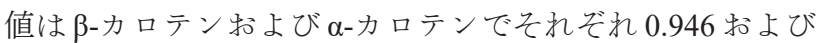
0.657 （Pはともに<0.0001）であった. $\beta$-カロテンについ て，“本紅金時”を除いたデータ（n=27）を用いても， 0.927
$(\mathrm{P}<0.0001)$ となり（推定式省略），この場合も $\mathrm{R}^{2}$ 值は $\alpha$-カ ロテンよりも $\beta$-カロテンの方が高かった.

以上の重回帰分析による両カロテン含量推定式の精度を K-fold 法により検証した結果を第 4 表に示す。最終的な指 標とした予測標準誤差対実測值標準偏差比（RPD）から, 「精度が高く問題のない推定が可能」との判定（Williams・ Norris, 2001; 山下ら，2018）が得られたのは 3 区画 15 個体 の平均值をデータ単位とした場合の $\beta$-カロテン含量のみ で， $\alpha$-カロテン含量については「非常に精度が低く実用不 可」の判定になった.

\section{考察}

本研究から，ニンジンの $\beta$-カロテン含量については, 収穫個体の根直径，根水分抏よび葉重を用いた推定式によ り，比較的高い精度で推定できる可能性が示された。

重回帰分析で得られた推定式の係数からは，根直径が太 く，根水分が少ない臣両カロテン含量が，また，葉重が 軽い汇ど $\beta$-カロテン含量が多くなると解釈できる。これ らの傾向は，個々の変数の単回帰分析での傾向（第 3 表） ともほぼ一致した．唯一， $\beta$-カロテン含量 $(n=108)$ にお ける根水分だけは，正負符号が異なった。しかし，この場 合の $\mathrm{R}^{2}$ は 0.209 と低く, “本紅金時”を除いた場合 $(\mathrm{n}=81)$ や，品種ごとの $\beta$-カロテン含量と根水分の関係も負であっ た（データ略）ことを勘案すると，根水分についても重回 帰で示される傾向を優先して差し支えないと思われる。こ らいった傾向が生じるメカニズムについては，不明確な点 も多いが，例觉ば，植物体に水分ストレスが生じると，糖 含量の増加を経て $\beta$-カロテンの増加につながるといら森 （1986）の説と整合性がある。 また，根直径については， 
第 4 表 K-fold 法データ分割によるカロテン含量推定精度の検証

\begin{tabular}{|c|c|c|c|c|c|c|c|c|}
\hline & & \multicolumn{3}{|c|}{ 検量線作成群 } & \multicolumn{4}{|c|}{ 検量線評価群 } \\
\hline & & $\mathrm{n}$ & $\mathrm{R}^{2}$ & $\mathrm{SEC}^{\mathrm{z}}$ & $\mathrm{n}$ & $\mathrm{R}^{2}$ & SEP $^{\mathrm{y}}$ & $\mathrm{RPD}^{\mathrm{x}}$ \\
\hline \multirow{3}{*}{$\begin{array}{l}1 \text { 区画（1 反復） } 5 \text { 個体の平均值を } \\
\text { データ単位とした場合 }\end{array}$} & $\beta$-カロテン & 72 & 0.829 & 6.7 & 36 & 0.820 & 6.7 & 2.4 \\
\hline & $\beta$-カロテン w & 54 & 0.744 & 7.0 & 27 & 0.735 & 7.0 & 2.0 \\
\hline & $\alpha$-カロテン w & 54 & 0.462 & 5.0 & 27 & 0.453 & 4.9 & 1.4 \\
\hline \multirow{3}{*}{$\begin{array}{l}3 \text { 区画（3反復） } 15 \text { 個体の平均值を } \\
\text { データ単位とした場合 }\end{array}$} & $\beta$-カロテン & 24 & 0.950 & 3.6 & 12 & 0.931 & 4.2 & 3.7 \\
\hline & $\beta$-カロテンw & 18 & 0.928 & 3.6 & 9 & 0.915 & 3.6 & 3.8 \\
\hline & $\alpha$-カロテン w & 18 & 0.664 & 3.3 & 9 & 0.692 & 2.9 & 2.1 \\
\hline
\end{tabular}

データ全体を無作為に 3 等分割後, 任意の 1 グループを検量線評価群，他の 2 グループを検量線作成群とし，グルー プを順次入れ替えて 3 回の検証を行い, 平均值を算出した

$\mathrm{z}$ 検量線標準䛊差 $(\mathrm{SEC})$ は $\left[\Sigma(\mathrm{Xi}-\mathrm{Yi})^{2} /(\mathrm{n}-\mathrm{p}-1)\right]^{1 / 2}$ で算出され，ここでXi は個々の実測值，Yi は個々の推定值，nは データ数, pは推定のための重回帰式に打ける独立変数の数を示す（夏賀ら，1992）

y 予測標準誤差 $(\mathrm{SEP})$ は $\left\{\Sigma[(\mathrm{Xi}-\mathrm{Yi})-(\mathrm{Xav}-\mathrm{Yav})]^{2} /(\mathrm{n}-1)\right\}^{1 / 2}$ で算出され，ここでXav は実測値の平均值，Yav は推定値 の平均值を示す (夏賀ら, 1992)

${ }^{x}$ RPD は実測值標準偏差／SEP で算出され， 2.3 : 非常に精度が低く実用不可， $2.4 \sim 3.0$ : 精度が低いが大まかな推 定可能，3.1〜 4.9: 精度が高く問題のない推定が可能，5.0-6.4: 非常に精度が高い，6.5〜8.0: 特に精度が高く品 質管理分析に相当， $8.1 \leqq:$ 極めて精度が高く化学分析と同等，という目安が設定されている（Williams・Norris， 2001; 山下ら, 2018)

w“本紅金時”を除外

根の肥大程度が大きいほど解糖系が促進され，相対的に多 量のピルビン酸拈よびュエンザイムAが生産されること により，その下流位置するカロテノイド生合成経路 （五十嵐，1997）も促進されたことが考光られる。ニンジン の根の肥大程度とカロテン含量に関係する先行研究として は次のものがある. Kidmoseら（2004）はニンジンを根直 径抢よび根重を基準として収穫時に 4 水準の大きさに分類 し， $\beta$-拉よび $\alpha$-カロテン含量を測定したところ，ニンジン の大きさと両カロテン含量との関係は明確でなかったこと を報告している.この結果は本研究とは異なるが，その原 因として本研究では複数の独立変数から解析する重回帰分 析を行っていることが考兄られる. 葉重については先行研 究での知見がないため, 現時点での考察は困難である.

前述した全式において，根色すなわち $\mathrm{L}^{*}, \mathrm{a}^{*}, \mathrm{~b}^{*}$ 特よび それらを組み合わせた独立変数を当てはめない方が従属変 数をよく説明できたことは予想外であった，例えば “本紅 金時’を除いた 3 反復 15 個体の平均值を 1 データとして $\beta$-カロテン含量推定式を根色のみで求めると $(n=27)$, 独 立変数は $\mathrm{a}$ * および $\mathrm{b}^{*}$ が選択されたが， $\mathrm{R}^{2}$ 捻よび検量線標 準誤差（SEC）はそれぞれ 0.773 打よび $6.1 \mathrm{mg} ・ \mathrm{~kg}^{-1} \mathrm{FW}$ 程 度であり，推定の精度は明らかに低かった。 この原因とし ては芯部の測定ができなかったことが考兄られる，芯部面 積は根面積の約 $18 \%$ に相当したことから，この部分の適 当な測定法が見出されれば，根色による推定の精度は向上 するかもしれない。

さて, 本研究では前述のように複数の品種打よび栽培年 をまとめて 1 つ推定式で表しているが，品種拉よび栽培 年の異なるニンジンが厳密に 1 つの式に当てはまるかにつ いて確認して打く必要があ万ら。そこで，3反復 15 個体 の平均值を 1 データとした $\beta$-カロテン含量の推定に打いて
共分散分析を行った。 その結果，1998年において品種を 要因とすると差なし $(\mathrm{P}=0.393), 1999$ 年に打いて品種を 要因とすると差あり $(\mathrm{P}=0.025)$, “向陽二号”に沏いて栽 培年を要因とすると差なし $(\mathrm{P}=0.115)$ となった（すべて $\mathrm{n}=9$ で交互作用なし)。つまり，1999年の “向陽二号” と “新黒田五寸’は2つの推定式に5\%水準で分かれるといら ことになる。本研究では汎用性のある簡易推定を目標とし ていることからこれらを1つの推定式に集約しょうとして いるが，推定式は品種によって異なる可能性もあり，共通 式とすることの妥当性については実際に利用する個々の場 面で求められる精度に応じて判断する必要があろう.

また，その他の注意点として，十分な精度が得られたの は 15 個体の平均值を用いた場合に限られるといらことが 挙げられる. このことは, 従属変数と独立变数との関係に 個体差があることを意味している，よって，推定式は個々 のニンジンのカロテン含量を高精度に予測することは難し い. しかし, 圃場間や試験区間といった集団単位間の比較 には適応できる可能性がある。

本研究の検討結果は, 有機溶媒や分析機器を用いず, 根 直径, 根水分拈よび葉重を測定するのみでニンジンのカ口 テン含量を推定する方法を確立するための参考となる．使 用する機器は定温乾燥器と電子天秤の久であることから, 推定法が確立できれば化学実験設備の整っていない調査拠 点をはじめ学校での農と食に関する実習など広い範囲で活 用できる可能性がある。 しかし，本研究における供試品種 は少なく，かつ1地域から得られた事例的な結果である. 今後はこれらの点を考慮しながら本研究結果の適応範囲を 確認するとともに, 推定式を構成する変数が選ばれた生理 的な根拠の究明が必要と思われる。 


\section{摘 要}

ニンジンのカロテン含量を, 一般の分析法によらず簡易 に把握することを目途とし, 収穫したニンジンの特性とカ ロテン含量の関係を分析した. 供試ニンジンは静岡県伊豆 の国市に招いて1998扣よび1999年に栽培した“本紅金 時’, ‘向陽二号’, ‘新黒田五寸’である. カロテン含量を 従属変数, 根色 ( $\left.\mathrm{L}^{*}, \mathrm{a}^{*}, \mathrm{~b}^{*}\right)$, 水分, 形状打よび生育量 を独立変数として重回帰分析を行った。 その結果, $\alpha$-カ口 テン含量（“本紅金時”を除く）は独立変数を根直径およ び根水分とした最適式であっても精度は低かった $\left(\mathrm{R}^{2}=0.692, \mathrm{RPD}=2.1\right)$ が, $\beta$-カロテン含量は独立変数を 根直径, 根水分扣よび葉重とした場合に高い精度 $\left(\mathrm{R}^{2}=0.931, \mathrm{RPD}=3.7\right)$ の推定式が得られた. ただし，共 分散分析の結果から ‘向陽二号’ と “新黒田五寸’の $\beta$-力 ロテン含量推定式はわずかに異なることが示唆された。 ま た，十分な精度の推定には，同じ条件で栽培されたニン ジン 15 個体の平均值を用いる必要があったことから，こ の推定式は, 個々のニンジンのカロテン含量の予測は難し いものの, 群落単位間の比較には適応できる可能性があっ た.

謝 辞 (公財) 農業 - 環境 - 健康研究所の田村夕利子氏 および (一社) MOA 自然農法文化事業団の山本秀治氏に はニンジンの栽培に执いてご協力いただいた。 ここに感謝 申し上げます。

\section{引用文献}

Barba, A. I. O., M. C. Hurtado, M. C. S. Mata, V. F. Ruiz and M. L. S. Tejada. 2006. Application of a UV-vis detectionHPLC method for a rapid determination of lycopene and $\beta$-carotene in vegetables. Food Chem. 95: 328-336.

Biswas, A. K., J. Sahoo and M. K. Chatli. 2011. A simple UV-Vis spectrophotometric method for determination of $\beta$-carotene content in raw carrot, sweet potato and supplemented chicken meat nuggets. LWT-Food Sci. Technol. 44: 18091813.

Britton, G. and F. Khachik. 2009. Carotenoids in food. p. 45-66. In: G. Britton, S. Liaaen-Jensen and H. Pfander (eds.). Carotenoids Volume 5: Nutrition and Health. Birkhäuser Verlag, Basel.

Cazzonelli, C. I. and B. J. Pogson. 2010. Source to sink: regulation of carotenoid biosynthesis in plants. Trends Plant Sci. 15: $266-274$.

Chew, B. P. and J. S. Park. 2009. The immune system. p. 363382. In: G. Britton, S. Liaaen-Jensen and H. Pfander (eds.). Carotenoids Volume 5: Nutrition and Health. Birkhäuser Verlag, Basel.

五十嵐 脩. 1997. カロテノイドおよび脂溶性ビタミンの 代謝. p. 232-241. 日本生化学会編. 細胞機能と代謝
マップ I. 細胞の代謝・物質の動態. 東京化学同人. 東京.

磯野浩太. 2011. 金時ニンジンのリコペン含量の簡易分別 定量法による測定值と色彩值 $\left(\mathrm{L}^{*}, \mathrm{a}^{*}, \mathrm{~b}^{*}\right)$ との相関に ついて．京都農林水技七農林七研報（農)。34: 9-12.

川城英夫. 2003. 生理 - 生態を生かす栽培の基本. p. 基 124の 4-18. 農業技術大系野菜編. 第 9 巻. ダイコ ン・ニンジン・カブ・ゴボウ. 農文協. 東京.

Khachik, F. 2009. Analysis of carotenoids in nutritional studies. p. 7-44. In: G. Britton, S. Liaaen-Jensen and H. Pfander (eds.). Carotenoids Volume 5: Nutrition and Health. Birkhäuser Verlag, Basel.

Kidmose, U., S. L. Hansen, L. P. Christensen, M. Edelenbos, E. Larsen and R. Nørbæk. 2004. Effects of genotype, root size, storage, and processing on bioactive compounds in organically grown carrots (Daucus carota L.). J. Food Sci. 69(9): S388-S394.

Krinsky, N. I. and E. J. Johnson. 2005. Carotenoid actions and their relation to health and disease. Mol. Aspects Med. 26: 459-516.

Mangels, A. R., J. M. Holden, G. R. Beecher, M. R. Forman and E. Lanza. 1993. Carotenoid content of fruits and vegetables: an evaluation of analytic data. J. Am. Diet. Assoc. 93: 284 296.

満田幸恵・新本洋士・小堀真珠子・津志田藤二郎. 2002. 高速液体クロマトグラフィーによる野菜のカロテノイ ド扣よびクロロフィルの同時分析. 日本食品科学工学 会誌. 49: 500-506.

森敏. 1986. 食品の質に及ぼす有機物施用の効果. p. 85-137. 日本土䁃肥料学会編. 有機物研究の新しい 展望. 博友社. 東京.

Nagata, M., Y. Noguchi, S. Imanishi and K. Sugiyama. 2008. A simple method for the estimation of alpha- and beta-carotene in carrots. Acta Hortic. 768: 565-569.

中川祥治・田村夕利子・山本秀治・吉田企世子・善本知 孝. 2003. 有機質肥料执よび化成肥料で栽培したニン ジン（Daucus carota L.）に扎ける生育量差の影響を除 去した品質比較. 土肥誌. 74: 45-53.

夏賀元康・川村周三・伊藤和彦. 1992. 近赤外分光法によ る穀物成分測定の精度（第 1 報）一北海道産小麦の水 分，タンパク質，灰分について一. 農機誌. 54(1): 8996.

Nicolle, C., G. Simon, E. Rock, P. Amouroux and C. Rémésy. 2004. Genetic variability influences carotenoid, vitamin, phenolic, and mineral content in white, yellow, purple, orange, and dark-orange carrot cultivars. J. Amer. Soc. Hort. Sci. 129: 523-529.

R Development Core Team. 2017. R: A language and environment for statistical computing. R Foundation for Statistical 
Computing. Vienna, Austria. <http://www.R-project.org>.

Rock, C. L. 2009. Carotenoids and cancer. p. 269-286. In: G.

Britton, S. Liaaen-Jensen and H. Pfander (eds.). Carotenoids Volume 5: Nutrition and Health. Birkhäuser Verlag, Basel.

Seljåsen, R., H. L. Kristensen, C. Lauridsen, G. S. Wyss, U. Kretzschmar, I. Birlouez-Aragone and J. Kahl. 2013. Quality of carrots as affected by pre-and postharvest factors and processing. J. Sci. Food Agric. 93: 2611-2626.

Takahata, Y., T. Noda and T. Nagata. 1993. HPLC determination of $\beta$-carotene content of sweet potato cultivars and its relationship with color values. Japan. J. Breed. 43: 421-427.

Taungbodhitham, A. K., G. P. Jones, M. L. Wahlqvist and D. R. Briggs. 1998. Evaluation of extraction method for the analysis of carotenoids in fruits and vegetables. Food Chem. 63: $577-584$.

塚澤和憲. 2002. 野菜における還元型ビタミンC及び $\beta$ カロテン含有量の簡易分析法の検討. 埼玉農林総研セ 研報. 2: 43-46.
内田 治. 2013. SPSSによる回帰分析. p. 50-51. オーム 社. 東京.

渡辺慶一・斎藤忠雄・広田才之・高橋文次郎. 1988. ニン ジンのカロチノイド色素の系統間差異. 日本食品工業 学会誌. 35: 315-320.

Williams, P. C. and K. Norris. 2001. Near infrared technology in the agricultural and food industries, 2nd Edition. p. 145169. American Association of Cereal Chemists, Minnesota.

山下有希・平岩 確 - 遠山孝通・森崎耕平・浅野智也・黒 野綾子・伊藤 真・池田彰弘. 2018. 近赤外分光法に よる「きぬあかり」と「ゆめあかり」の原麦蛋白質含 量の簡易測定. 愛知農総試研報. 50: 71-73.

Yeum, K.-J., G. Aldini, R. M. Russell and N. I. Krinsky. 2009. Antioxidant/pro-oxidant actions of carotenoids. p. 235-268. In: G. Britton, S. Liaaen-Jensen and H. Pfander (eds.). Carotenoids Volume 5: Nutrition and Health. Birkhäuser Verlag, Basel. 